\title{
Managing university landscape and infrastructure towards green and sustainable campus
}

\author{
Muhammad Anis ${ }^{1}$, Adi Zakaria Afiff ${ }^{2}$, Gandjar Kiswanto ${ }^{3}$, Nyoman Suwartha $^{4, *}$ and Riri Fitri Sari ${ }^{5}$ \\ ${ }^{1}$ Department of Metallurgy and Material Engineering, Faculty of Engineering, Universitas Indonesia, Kampus UI Depok, Depok \\ 16424, Indonesia \\ ${ }^{2}$ Department of Accounting, Faculty of Economy and Business, Universitas Indonesia, Kampus UI Depok, Depok 16424, Indonesia \\ ${ }^{3}$ Department of Mechanical Engineering, Faculty of Engineering, Universitas Indonesia, Kampus UI Depok, Depok 16424, \\ Indonesia \\ ${ }^{4}$ Department of Civil Engineering, Faculty of Engineering, Universitas Indonesia, Kampus UI Depok, Depok 16424, Indonesia \\ ${ }^{5}$ Department of Electrical Engineering, Faculty of Engineering, Universitas Indonesia, Kampus UI Depok, Depok 16424, Indonesia
}

\begin{abstract}
Landscape and infrastructure are two main basic aspects which play a significant role for any universities in achieving environmental, social-behavioural, or aesthetic outcomes. This paper describes the setting and infrastructure management at the Universitas Indonesia (UI) as a continuous effort towards green and sustainable campus. Some developments and improvements have been made during the last three years, such as forest city maintenance, development of pedestrian boulevard, and installation of road marks and traffics signs. In addition, infrastructures have been improved by replacing conventional lamps with LED type ones, development of real-time energy consumption monitoring system, green chilling system, solar photo-voltaic development, solar cooling absorption chiller system, air conditioning with VRF/VRV system, and preparation for green certified building. These improvements on campus setting and landscape are reflected on the UI GreenMetric 2017 results which ranked at \#23 worldwide with the score of 957 out of 1500 total score for "setting and infrastructure" category. With regards to these achievements, some challenges and strong commitment in sustainability policy need to be implemented in the forthcoming years to maintain the UI's vision to be a "world class sustainable university".
\end{abstract}

\section{Introduction}

Massive development worldwide in recent years brings significant indications that the future of the world is very much depending on the environment status. Global warming and climate change impacts at various sectors is a natural prove of the unsynchronized development and un-environment-friendly resources exploration. In order to mitigate serious impacts of climate change, several environmentalists and activists of various elements (government, NGO, society, higher education institutions, schools, etc.) have moved together to promote the save the environment movement. One of the example is the campaign by the Climate Reality Project, through a 24 Hours of Reality: Be the Voice of Reality [1]. Furthermore, as to raising international public awareness of global warming and reenergizing the environmental movement, Al Gore had presented a documentary movie ("An Inconvenient Sequel: Truth to Power") on the threat that climate change poses to the Earth - it's causes, effects and history and potential solutions to it. The recent COP 23 UNFCC conference in Bonn showcased the multiparty effort on achieving the Climate Change mitigation program.

At the higher education institutions (HEIs) level, universities play an important role as contributor to Greenhouse Gas Emission (GHG) from daily teaching and research-based activities. Many universities have been more aware with climate change issues and works together to minimize GHG emission and combat climate change impacts. There are many university networks on environment and sustainability that had been established at university, national, regional and global scale, such as Green Princeton, Sierranevada.com, Association for the Advancement of Sustainability in Higher Education (AASHE), Sustainable University Network (SUN) of Thailand, Campus Sustainability Network in Japan (CAS-Net Japan), International Sustainable Campus Network (ISCN), Sustainability Tracking, Assessment \& Rating System (STARS), UI GreenMetric World University Rankings, etc. Through such specific network, universities from developed and developing countries can share their best practice on sustainability policy and the implementation.

Known as the best campus in Indonesia according to the QS World Universities Ranking 2017/2018 (1 ${ }^{\text {st }}$ ranked in Indonesia, $54^{\text {th }}$ in Asia, $277^{\text {th }}$ in the world) [2] and ranked $>800$ in the THEs ranking 2017/2018 [3], Universitas Indonesia (UI) kept its predicate being the nation's oldest, most prestigious, and greenest campus. The university has continuously promoted awareness and sustainability program internally to create a better and greener living. Geographically, UI campus is located in two areas: Salemba (Jakarta) and Depok (West Java).

\footnotetext{
*Corresponding author: nsuwartha@eng.ui.ac.id
} 
As the main campus, Depok campus covered approximately $320 \mathrm{ha}$, recognized around $70 \%$ of the area with astonishing greenery as a city forest and an ideal landscape for academic nuance of beautiful and tradition tranquil (Fig. 1). As an educational institution with a world-class university perspective, UI has a vision to create an environment-based 'green campus' to more than its 50,000 inhabitants.

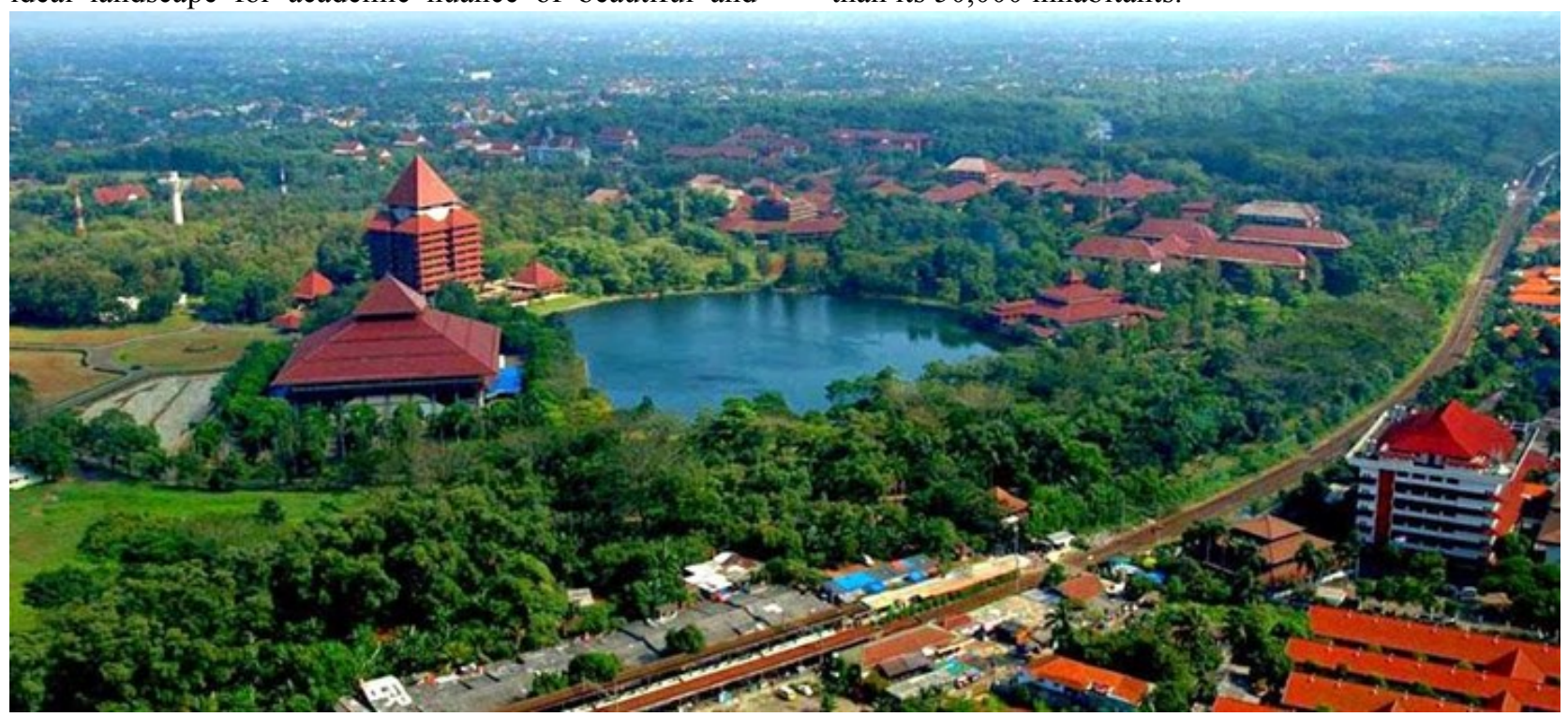

Fig. 1. Landscape of Universitas Indonesia Depok campus as one of the greenest campus in the country

\section{University policies on campus sustainability}

UI has a strong commitment to achieve green and sustainable campus which can be seen from several Rector's Act issued on 2011, related to environmental and sustainability policy on green transportation, the use of bicycle and pedestrian, waste and toxic waste management, limitation on of toxic used for drinks and foods packaging, mitigation and adaptation of global climate change, reducing papers and plastic used, clean water conservation, and energy conservation program.

\subsection{University landscape}

In term of campus setting and infrastructure, UI maintains the present condition with continuous development and improvement. Based on the allocation of campus area plan, there are four land use type can be identified in UI Depok campus: physical building and green landscape buffer of 170 ha, water ecosystem of 30 ha, city forest area of 100 ha, and supporting facilities, infrastructure, including environment buffer area of 12 ha.

\subsubsection{Building and green landscape}

One of the UI commitments in creating green campus is represented by the new library building "Crystal of Knowledge" at Depok campus which was developed by adopting sustainable concept. Built on a 33,000-meter square area, the building is considered as the largest library in Southeast Asia. It is equipped with a cooling system water cooled chiller, solar panels, green-roof, and smoke-free area (Fig. 2). The library has the capacity to accommodate about 20,000 visitors per day and have collection of $1,500,000$ books [4].

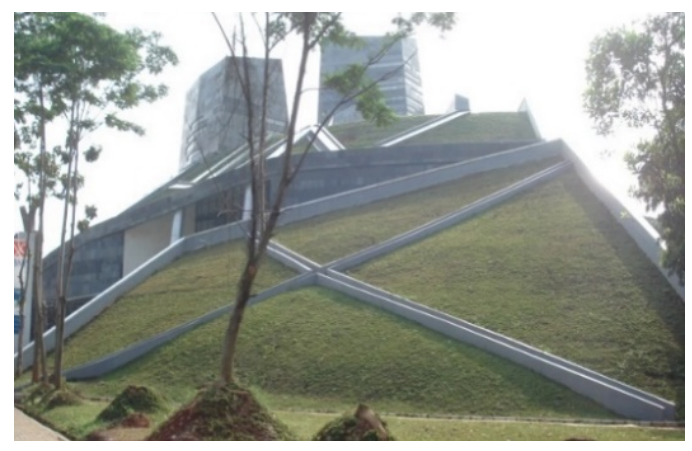

Fig. 2. The green-roof at new library building

Other building which adopted the green-building concept is the Faculty Club (FC) building. It was built in \pm 10 ha area as an integrated space for sports (national Olympic standard pool, tennis court, golf driving, gymnasium) meeting rooms, restaurant, etc. This building was equipped with thin film solar PV capacity of $25 \mathrm{~kW}$ peak, to supply university's electricity demand [5]. Since 2017, the integrated faculty club was cooperatively managed by UI and Relife Property Company (Felicity Festival).

As additional unique features to the existing green landscape and vegetation, there are about 9 big African Baobab trees aging over 200 years have been relocated and planted in UI Depok campus.

\subsubsection{Water ecosystem}

Apart from the beautiful and comfortable green landscape, there are series of lakes inside UI Depok campus aimed to function as the water storage and 
absorption/groundwater recharge area. Six lakes were built in cascade and called as KAMPUS (abbreviation of the first character of 6 species name of Indonesian trees), from upstream to downstream:

1) Kenanga lake $\left(28,000 \mathrm{~m}^{2}\right)$, located between Rectorate building and UI Mosque, built in 1992

2) Aghatis lake (20,000 $\mathrm{m}^{2}$ ), located between Faculty of Mathematics and Natural Science and Jakarta State Polytechnic, built in 1995.

3) Mahoni lake $\left(45,000 \mathrm{~m}^{2}\right)$, located aside the main street of South Boulevard (Eastern side of Faculty of Humanities and Faculty of Psychology, and western side of Faculty of Economics), built in 1996.

4) Puspa lake $\left(20,000 \mathrm{~m}^{2}\right)$, located between Lake Ulin and Lake Mahoni, built in 1995.

5) Ulin lake $\left(72,000 \mathrm{~m}^{2}\right)$, located between Lake Puspa and Lake Salam, built in 1998.

6) Salam lake $\left(42,000 \mathrm{~m}^{2}\right)$, located in lowest part series of Lake Ulin and Lake Puspa, built in 1998.

The lakes, as a natural water body are used as habitat for more than hundred species of fish and invertebrate (microorganism). It is also being used as an object for several researches on surface water quantity and quality, marine laboratory, as well as sports and sight-seeing spot.

\subsubsection{City forest}

Since the first stage of Depok campus development, UI inherited large area of tropical rainforest which is known as city forest. It has unique characteristics with three types of advanced ecosystem, they are: (1) Tree ecosystem from eastern part of Indonesia; (2) Tree ecosystem from western part of Indonesia; and (3) local original vegetation complex combined with Tectona Grandis/Teak Tree (so called Jati Mas in Indonesian) Forest [4].

Total area for reforestation is allocated approximately 100 ha. Beside reforestation, Sub-Directorate of Campus Environment Development (PLK) UI also promotes an enhancement planting program aimed to enriching trees variety. It is expected to reach the target of $50 \%$ of the 680 species of trees planted by 2017, since its first initiation of about 27,350 trees planted in 2013. Several events related to environmental sustainability regularly conducted, such as workshop on planting "Belimbing tree" (star-fruit tree) in vacant land inside Depok campus areas that organized by student association involving local community around UI, reforestation program by PLK in corporation with some CSR of private companies.

Since 2013 UI implemented a Green Campus program. The program aimed at creating campus as a centre of activity and empowerment of stakeholders and strategic partners in the conservation of the environment, prevent pollution and damage as well as the creation of clean and green campus. The program covers several activities supporting sustainable campus policy such as: water conservation and utilization; renewable energy and utilization; land utilization; and minimizing waste generation.

\subsubsection{Supporting facilities \& infrastructures}

Several facilities and infrastructures that supporting the green-building and landscape inside the UI Depok campus are summarised as the following [4].

Integrated Laboratory and Research Center (ILRC) building was built with an aim to be the home for integrated laboratory and a center for research administration in UI. One of the examples is the development of the UI-Olympus Bioimaging Center, as the first bioimaging laboratory established in Indonesia. The ILRC building was designed in a half-circle shape, specifically aimed to receive the sun light equally distributed to each rooms of the building.

The Makara \& Art Center building establishment is one of the UI efforts as an education institution to support the nurture of the soft skill competency of the students. The area of $11,600 \mathrm{~m}^{2}$ building is located beside the UI Mosque and Kenanga lake. The building design concept is to create a magic box and it is planned to be a unique building that motivates and encourages the student's talent in arts world. This building is designed and equipped with the green chiller which is the $1^{\text {st }}$ green chiller implements in Indonesia.

Solar Air-conditioning System are introducing to mitigate environmental pollution and reduce the greenhouse gas emissions of a building inside the university. A research collaboration in 2014 has resulted in a $239-\mathrm{kW}$ solar air-conditioning system using a single-double effect combined absorption chiller. It was installed in a building at the Faculty of Engineering, Universitas Indonesia [6].

Dormitory is provided to first year students. The building covers an area of $25,534 \mathrm{~m}^{2}$, surrounded by lakes and greenery, and accommodated 400 male students and 445 female students.

Campus Bus is available for free andi s dedicated to providing green public transportation which can reduce emission. In 2017, UI Depok campus maintain approximately 20 campus bus called "yellow buses" (bis kuning). They serve for students, staff, and public in regular routes inside the campus area from Monday to Friday, from 7:00 am to 9:00 pm and Saturday from 7:00 am to 2:00 pm.

Campus Bicycle, as an UI commitment and support in implementing "go-green" campaign, more than 300 bicycles were provided for free-of-charge in Depok campus. This facility is open for students and academic staff to travel from one faculty to another or buildings inside campus. The students need to show their UI student card to the rental officers who manage the bicycle shelter. The bicycle must be used on bicycle pathways and it must be returned to the bicycle shelters by $5: 00 \mathrm{pm}$. 


\section{Towards green and sustainable campus}

\subsection{Managing of campus setting}

Campus setting plays significant role for creating a more convenient and better academic atmosphere. On the other hand, it is undeniable that infrastructure also plays an important role in supporting various activities for any institution to function properly. Hence, better management on campus setting along with related infrastructure may significantly contribute to nurture the spirit of learning and intensifies connection of academic community to the surrounding society. The following section describes some main activities that has been carried out by Universitas Indonesia in order to create and provide open- and green-spaces, green public transport, and environmentally related programs

\subsubsection{Maintenance of trees in the university's city forest}

UI City Forest is designated as a conservation forest area based on Jakarta Governor's Decree No. 869 in 2004. Besides the function as absorption area and research on biodiversity, the city forest also designated as a conservation area of germplasm and habitat of various wildlife. Thus, it is very much helps students who are studying tree identification. The UI Forest City UI stores approximately 186 species of trees that come from various regions in the archipelago. This makes 'UI City Forest' as the urban forest with highest variety of tree species compared to other urban forest in Jakarta. In addition, UI City Forest becomes a house for at least 30 species of birds.

However, due to the aging trees and the lightning, storm, and typhoon which are quite dominant during the rainy season, many fallen trees events were found around the campus of UI. Hence, maintenance activities and pruning of trees that prone to fall are conducted by Directorate of Facilities Maintenance and Management (DPPF) to minimize and eliminate the potential danger of fallen trees.

Identification of the potential hazard of fallen trees is carried out through inspection of the condition of existing timber trees in the main lane and surrounding building facilities. This activity results in 202 fallenprone trees on the main lane were pruned and logged intensively.

In 2017, the maintenance activities of fallen-prone trees covers pruning (16\%), logging (37\%), and elimination $(47 \%)$. Pruning is aimed at reducing the burden of trees and the risk of fracture of branches and twigs due to trees too dense. Logging is aimed to reduce the burden of trees and the risk of broken branches and fallen trees (broken at base). Elimination is aimed to eliminate the risk of fallen trees due to the condition of trees that severely suffered and damage due to pest diseases. Replanting and reforestation have been conducted in several locations to replace the fallen and eliminated trees.

\subsubsection{Improvement of road and pedestrian highway}

Apart of the city forest maintenance, several improvements activities in setting and infrastructure were also been conducted (Fig. 3). The scope of this works include renovation work of road cleanliness, road markers, roads'median, pedestrian way, open and closed channels, bus stop, bicycle track, bicycle stop, parking lot, curb grass, park (all parks including those above pedestrian), pedestrian highway, drainage system (water channels), grass areas (parks), bicycle tracks, bus stops, bicycle shelters, ornamental plants throughout the campus area of UI Depok.

The idea of this improvements are to provide infrastructures that directly support green- and publictransportation which meet the standards quality. For example, the pedestrian highway were developed as much as possible to be convenience for all pedestrian including for person with disability.

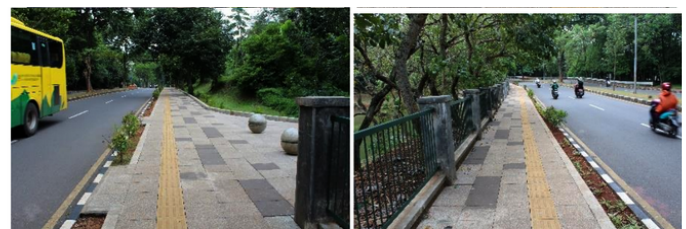

(a) Renovation of the pedestrian highway

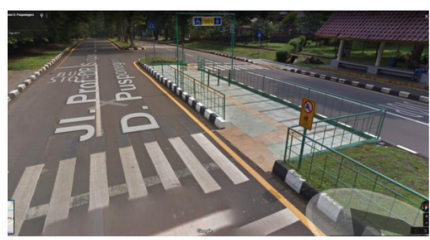

(b) Development of pedestrian road crossing pathways

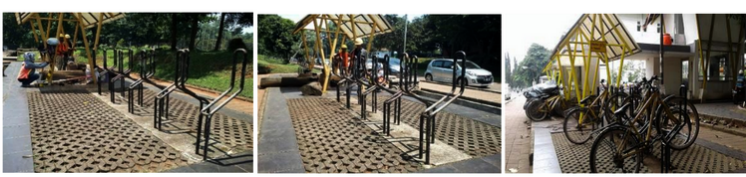

(c) Rejuvenation of bicycle shelter and improvement of 120 bicycle track portal

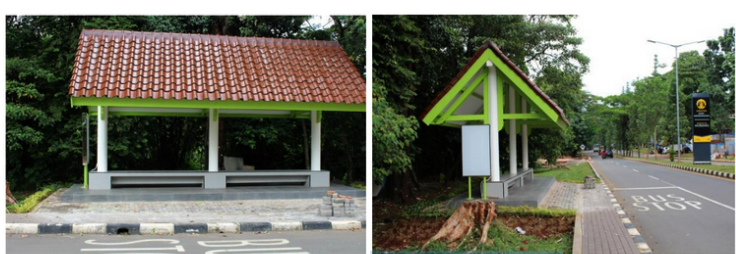

(d) Development of additional bus stop
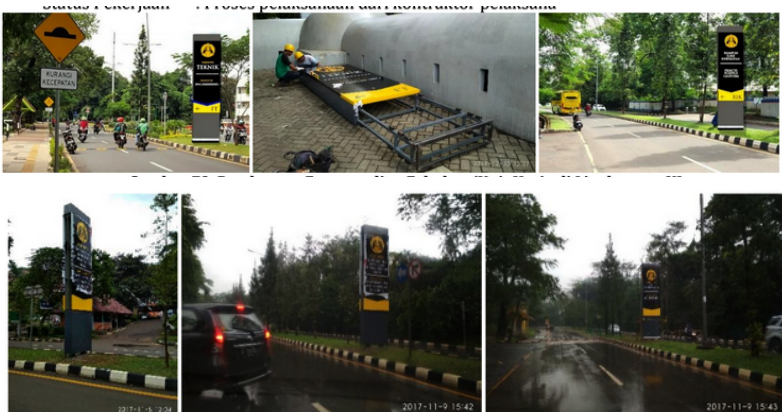

(e) Installment of freestanding signs at faculty's entrances

Fig. 3. Several improvements on public transport infrastructures 


\subsection{Developing infrastructure}

green-building

and

In Depok campus, there are several buildings that dedicated as green-building model such as the Integrated Laboratory and Research Center (ILRC) building, new library building, Art and Culture Center, and the Integrated Faculty Club (IFC) building. As the UI commitment to save energy and support green environment, there is new regulation for any construction should adopt the green-building concept as much as possible.

\subsubsection{Proposing LEED green building certification}

One more new green-building is being developed since 2017 known as the student activity center (Pusgiwa) as shown in (Fig. 4). The first Pusgiwa building was developed in 1989 served for only 15 students activities unit. The new Pusgiwa building within an area of 13,296 $\mathrm{m}^{2}$ (GFA) is provided for 45 student activity units. The building was designated to be first building model acknowledged by Leadership in Energy and Environmental Design (LEED) green building certification.

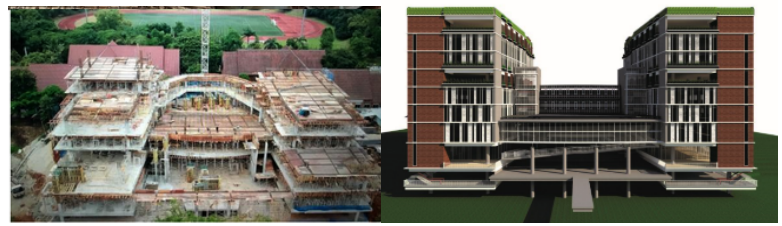

Fig. 4. Development of the new Pusgiwa (students activities center) building

The new building will be used as a student spot center in addition to the existing spot center in UI new library building. The idea is to make this Pusgiwa as a place to gather, discuss, and engage students, both in the field of academic, sports, and arts. Hence, we want this new Pusgiwa area to be completely equipped in terms of facilities.

\subsubsection{Promoting renewable energy development}

In line with the green-building concept, UI also promoting several renewable energy development. One of the massively developed is the installation solar PV at several buildings at faculties and university buildings. Those buildings are the MRPQ building Faculty of Engineering with the capacity of $2.5 \mathrm{~kW}$ peak and at the Integrated Faculty Club (IFC) with the of capacity 25 $\mathrm{kW}$ peak, etc.

In 2018, several solar PV will be developed at cluster of science of helath (RIK). The total production of solar PV installation in UI Depok campus by the end of 2018 is targeted to be approximately $140 \mathrm{kWP}$.

\subsubsection{Monitoring energy consumption}

In 2017, the university developed a new website system aimed to monitor the energy consumption and sustainability. At this moment, the system can be accessed internally through the sinergil.ui.ac.id/ems_ui/. (Fig. 5) shows the front page of the website.

By using this website, the UI management can monitor the energy consumption form each faculty in real-time (daily, hourly). For example, the red mark colour, shows the over-limit energy consumption, while the green mark colour indicates the normal energy consumption. It is expected with the new website system all information related to energy consumption and campus sustainability can be accessed by stakeholders in UI.

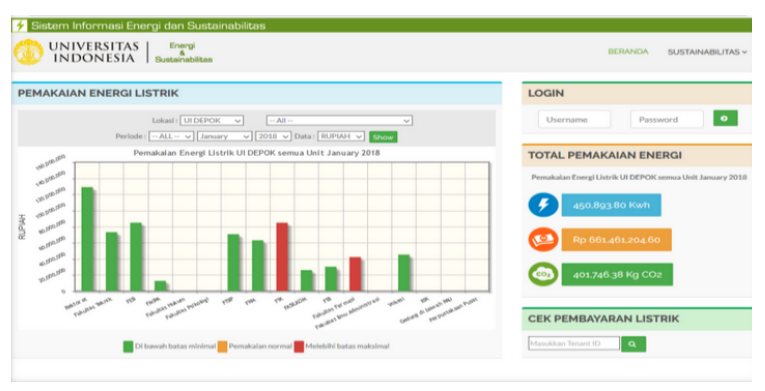

Fig. 5. Front page of the UI's Energy Information System.

In the sustainability program of energy, during 2017 several replacements of conventional lamps with LED type have been conducted. This will reduce the energy consumption to about $50 \%$ (the LED lamp has power consumption requirement of about 50\% lower than conventional lamps with similar quality).

\subsection{University achievement}

Based on the UI GreenMetric 2017 ranking results, for setting and infrastructure category (Table 1), UI collects higher points from three main indicators; the first is the ratio of open space area towards total area; secondly, the ratio of open space area towards campus population; and the third is the university budget for sustainable effort.

Table 1. Universitas Indonesia' scores for setting and infrastructure based on UI GreenMetric 2017 result.

\begin{tabular}{|c|c|c|}
\hline Indicators & Score & Max. Score \\
\hline SI1 & 295 & 300 \\
\hline SI2 & 203 & 300 \\
\hline SI3 & 122 & 200 \\
\hline SI4 & 67 & 200 \\
\hline SI5 & 70 & 300 \\
\hline SI6 & 200 & 200 \\
\hline Total score & 957 & 1,500 \\
\hline
\end{tabular}

SI1: the ratio of open space area towards total area; SI2: the ratio of open space area towards campus population; SI3: area on campus covered in forest; SI4: area on campus covered in planted vegetation; SI5: area on campus for water absorbance; SI6: university budget for sustainable effort. 
With a total score of 957 for setting and infrastructure category (overall score for 6 categories of UI Greenmetric was 6,519), UI stays at rank \#23 [7].

If we look more detail into this category, compared with the results in the last four years (Fig. 6), there are decreasing score for the area on campus covered in forest (SI3); the area on campus covered in planted vegetation (SI4); and the area on campus for water absorbance (SI5). These three decreasing scores is might be due to the effect additional of new participants of UI Greenmetric in 2017 (about 100 universities) which have better performance of setting and infrastructure in their respective campus. This is because the calculation algorithm for scoring of this category/indicators is by normalising the score based on the maximum score in regards to all participants [8]. In addtion, it obvious due to development of several buildings in UI Depok campus (university hospital, art center building, cluster for health and science building, integrated faculty club building, etc.) brought consequences to reduce the green open spaces and water absorbance area.

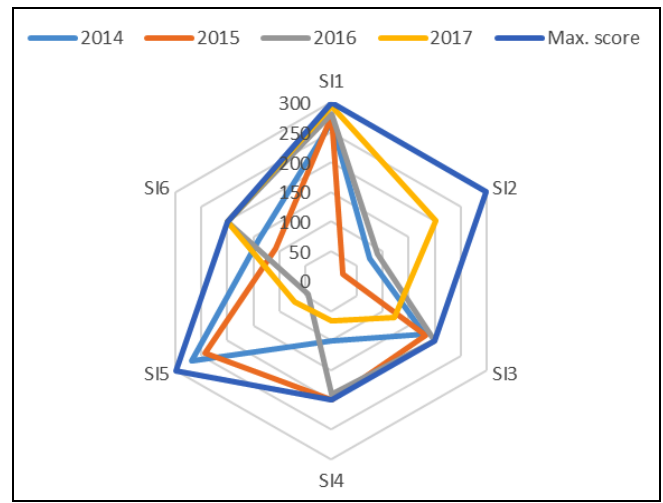

Fig. 6. The setting and infrastructure indicator's score of UI for the last 4 years.

However, for the other indicators (SI1 and SI6), UI has approximately reach the maximum scores. The setting and infrastructure category in UI GreenMetric contributes only $15 \%$ of overall score. Hence, the score for this category is not the merely significant factor in determining the final ranking result, because there are other categories such as energy and climate change $(21 \%)$, waste management $(18 \%)$, transportation $(18 \%)$, education $(18 \%)$, and water management $(10 \%)$ that should be considered for improvement [9].

\section{Concluding remarks}

With regards to the Strategic Plan 2012-2017, Universitas Indonesia will continue to realizing the program and policy particularly in setting and infrastructure sector to reach the university vision and mission in creating sustainable campus. For sure, to realizing a green and sustainable campus with ecofriendly based education infrastructure (eco-sciencepark) required strong commitment and supports from all faculties members, staff and students. This commitment includes university budget for research and sustainability operation which are also a significant issue in the near future. It is time to put priority of university policy on sustainability of each development sectors which finally contribute to the global trends in making the SDGs university report.

Acknowledgement. We would like to express our thanks to Directorate of Facilities Maintenance and Management (DPPF) Universitas Indonesia and UI GreenMetric Rankings ofice for providing relevant data and information.

\section{References}

1. The Climate Reality Project, 24 Hours of Reality: Resource Kit, Available online at https:/www.climaterealityproject.org/content/24hours-reality-resource-kit (1989)

2. QS World University Rankings 2016/2017, Available online at https://www.topuniversities.com/universityrankings/world-university-rankings/2016

3. The Times Higher Education World University Rankings 2015-2016, Available online at https://www.timeshighereducation.com/worlduniversity-rankings/2016/worldranking\#!/page/0/length/25/country/16/sort by/rank label/sort order/asc/cols/rank only

4. Suwartha, N., Sari, R.F., Widanarko, B., Rarasati, A., Zakaria, A.A., Towards Sustainable University through Setting and Infrastructure Development at the Universitas Indonesi, In: Proceeding of the $2^{\text {nd }}$ International Workshop on UI GreenMetric (IWGM 2016), Universitas Indonesia, Indonesia (1989)

5. Suwartha, N., Sari, R.F., Widanarko, B., Ilyas, T., Cultivating Green energy at the Universitas Indonesia Towards Sustainable Campus, In: Proceeding of the $3^{\text {nd }}$ International Workshop on UI GreenMetric (IWGM 2017), Istanbul University, Istanbul, Turkey (2017)

6. Hajime Yabase, H., Saito, K., Lubis, A., Alhamid, I., Nasruddin, Solar Air-Conditioning System at the University of Indonesia, International Journal of Technology, 7(2), pp. 212-218 (2016)

7. UI GreenMetric, UI GreenMetric World University Rankings, Available online at http://greenmetric.ui.ac.id/overall-ranking-2017/ (2017)

8. Suwartha, N., Sari, R. F., Evaluating UI GreenMetric as a tool to support green universities development: assessment of the year 2011 ranking, Journal of Cleaner Production, 61, pp. 46-53 (2013)

9. Lauder, A., Sari, R.F., Suwartha, N., Tjahjono, G., Critical review of a global campus sustainability ranking: GreenMetric. Journal of Cleaner Production, 108, pp. 852-863A (2015) 